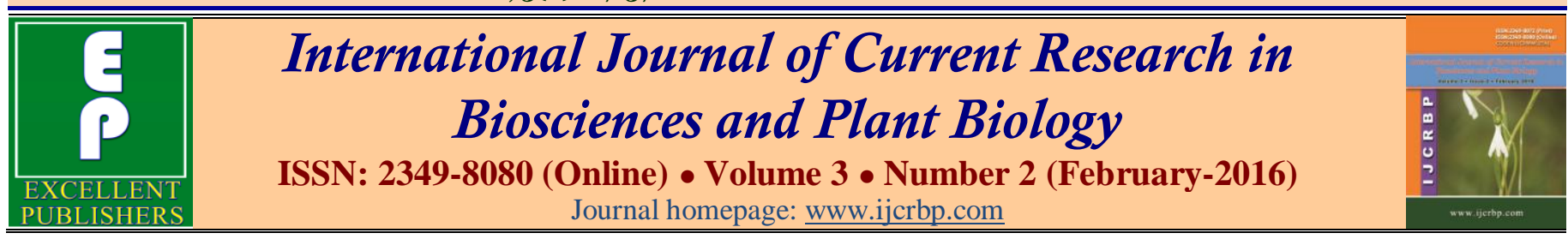

\title{
A Molecular Investigation of Asplenium: Asplenium kivuensis nov.* - A New Species from Kivu (Democratic Republic of Congo)
}

\section{Jean de Dieu MANGAMBU MOKOSO ${ }^{*}$, Steven JANSSEN², Elmar ROBBRECHT², Thomas JANSSEN3, Honorine NTAHOBAVUKA HABIMANA4 and van Ruurd DIGGELEN5}

\author{
${ }^{1}$ Université Officielle de Bukavu, Département de Biologie, Laboratoire de Systématique, Végétale et Biodiversité, B.P.57o, \\ Bukavu, DR Congo \\ ${ }^{2}$ Nationale Plantentuin van België and Domaine of Bouchout, Nieuwelaan 38, B-186o Meise, Belgium \\ 3Institut für Biologie, Humboldt-Universität zu Berlin, Unter den Linden 6 10o99, Berlin, Germany \\ ${ }^{4}$ Université de Kisangani, service de Palynologie et Biodiversité, B.P 2012, Kisangani, DR Congo \\ 5 Universiteit Antwerpen/ België, Ecosystem Management Research Group, Department of Biology Universiteitsplein 1-C B-261O \\ Antwerp-Wilrijk, Belgium \\ *Corresponding author.
}

\begin{abstract}
A bstract
Present study examined the phylogenetic structure of two species of the genus Asplenium L. [A. aethiopicum (Burm.f.) Bech, A. friesiorum C.Chr. and affinity) in Kivu (DR Congo) which are known to comprise several different morphotypes. In total, 15 specimens of A. friesiorum C.Chr. (and affinity) and 15 of A. aethiopicum (Burm.f.) Bech. were sequenced for three molecular markers $(\operatorname{trn} G, \operatorname{trn} L-F$ and $r p s 4-t r n S)$. Prior to analyzing the combined chloroplast data, each marker was examined separately to recognize the phylogenetic differences amongst the chloroplast datasets. Sequence datasets were analyzed using Maximum Likelihood and Bayesian Inference, in order to obtain solid phylogenetic results. To consolidate the phylogenetic information obtained, we observed the spores of corresponding herbarium specimens using scanning electron microscopy. Phylogenetic results demonstrated that each of the Asplenium L. species studied here comprises at least two clearly delimited subspecies in Kivu [A. friesiorum kivuensis Mangambu nov.* and A. friesiorum C.Chr.; A. aethiopicum (Burm.f.) Bech. subsp. aethiopicum and A. aethiopicum (Burm.f.) Bech. subsp. tripinnatum (Baker) A.F. Braithw]. The observed spores showed differences in shape and size between the subspecies studied of A. aethiopicum (Burm.f.) Bech., species A. friesiorum C.Chr. and A. kivuensis Mangambu nov.*.
\end{abstract}

\section{Article Info}

Accepted: 11 January 2016

Available Online: 06 February 2016

\section{Keywords}

Asplenium

Kivu Mountain

Molecular phylogenetic

New species

\section{Introduction}

Family Aspleniaceae is the largest phylum of the Pteridophyta. It is characterized by sores along the nervures with an elongated and membranous indusium. Sporangia species of this family have a wall formed of a single layer of cells, all from a single epidermal cell, and a basic number of chromosomes of $\mathrm{x}=36$ (http://www. aquaportail.com/definition-8912-leptosporangie.html).
It is a monogeneric family (Asplenium L.), cosmopolitan, comprising about 800 leptosporangiate ferns, terrestrial, epilithic and epiphytic (Kramer and Viana, 1990; Fischer, 1996; Matos et al., 2009), although several authors (Hasebe et al., 1994; Murakami and Moran, 1993; Ledis and Carmen, 2011) separated some species of Asplenium L. in different genera such as Phyllitis Newm., Camptosorus Rupr., Neottopteris J.Sm., Boniniella Hayata and Hymenasplenium Hayata. The 
genus is often subdivided into several genera and subgenera. Morton and Lellinger (1966) recognize Loxoscape T. Moore and placed the species with veins and sori occurring at an acute angle to the costa, and with rachises more or less scaly and sometimes hairy in Asplenium L section Sphenopteris Mett.

The occurrence of intermediate forms between these genera and sections render most of these classifications unsatisfactory. The classification followed here is conservative in that only two subgenera, Asplenium $\mathrm{L}$ and Ceterach Willd. are recognized. Asplenium L section Hymenasplenium (Hayata) K.Iwats. is widely accepted as a well-defined group (Mitui et al. 1989; Viane and Reichstein 1991; Murakami and Moran 1993) The section is defined by creeping rhizomes, dorsiventrally symmetrical steles, swollen stipe bases or trophopods, and chromosome numbers based on $\mathrm{n}=38$ or 39 . Asplenium obscurum Blume and A. unilaterale Lam. belong to this section (Roux, 2001).

Since 1950, several studies focused on the cytology, taxonomy, biosystematics and phylogenetics of some groups of Aspleniaceae. However, the systematics of species belonging to this family remained far from well known following various changes occurring on the species in different habitats (Iwatsuki, 1984; Tryon and Tryon, 1982; Matos et al., 2009; Mangambu et al, 2014a). The status of these genera remains unclear to be accepted, because the relationship to other Aspleniaceae groups is still uncertain (Matos et al., 2009; Ledis and Carmen, 2011). Studies based on molecular data, or combined molecular and morphological studies have brought together all the species of this family in a single genus Asplenium L. (Matos et al., 2009; Ledis and Carmen, 2011).

Apart from the $\operatorname{trn} G$ molecular marker commonly used for phylogenetic studies of Aspleniaceae and other Pteridophyta (Hasebe et al., 1994 and 1995; Gastony and Johnson, 2001; Testo and Watkins, 2011; Regalado and Carmen, 2011), we used two more other markers ( $\operatorname{trn} L-F$ and rps4-trnS) to clarify the phylogenetic status of two of Asplenium L. species from KBPN. Marker trnL-F was tested successfully by Schneider et al. (2005) and de Groot et al. (2011). The three markers ( $\operatorname{trn} G, \operatorname{trn} L-F$ and rps4-trnS) were used by Schneider et al. $(2005,2009)$ in their works, and all these markers were successful. In the current study, we determined the molecular sequences of two species Aspleniaceae (A. aethiopicum, A. friesiorum C.Chr. and affinity) using these three markers and we compared the molecular results with those of morphological descriptions.

\section{Materials and methods}

\section{Study area}

Created in 1970 to protect the eastern lowland Grauer's Gorilla (Gorilla beringei graueri) and their habitats (Mangambu et al., 2014a). Kahuzi Biega National Park (KBNP) is located in the Province of South Kivu, specifically in the southern part of the chain mountains Kivu-Ruwenzori axis NNE-SSW along to the west, the Albertan Rift (Mangambu et al., 2014b). This Park covers $6000 \mathrm{~km}^{2}$ of area (Fig. 1) and includes two main peaks which are extinct volcanoes, namely Kahuzi (3326 $\mathrm{m}$ of altitude) and Biega (2790 m of altitude).

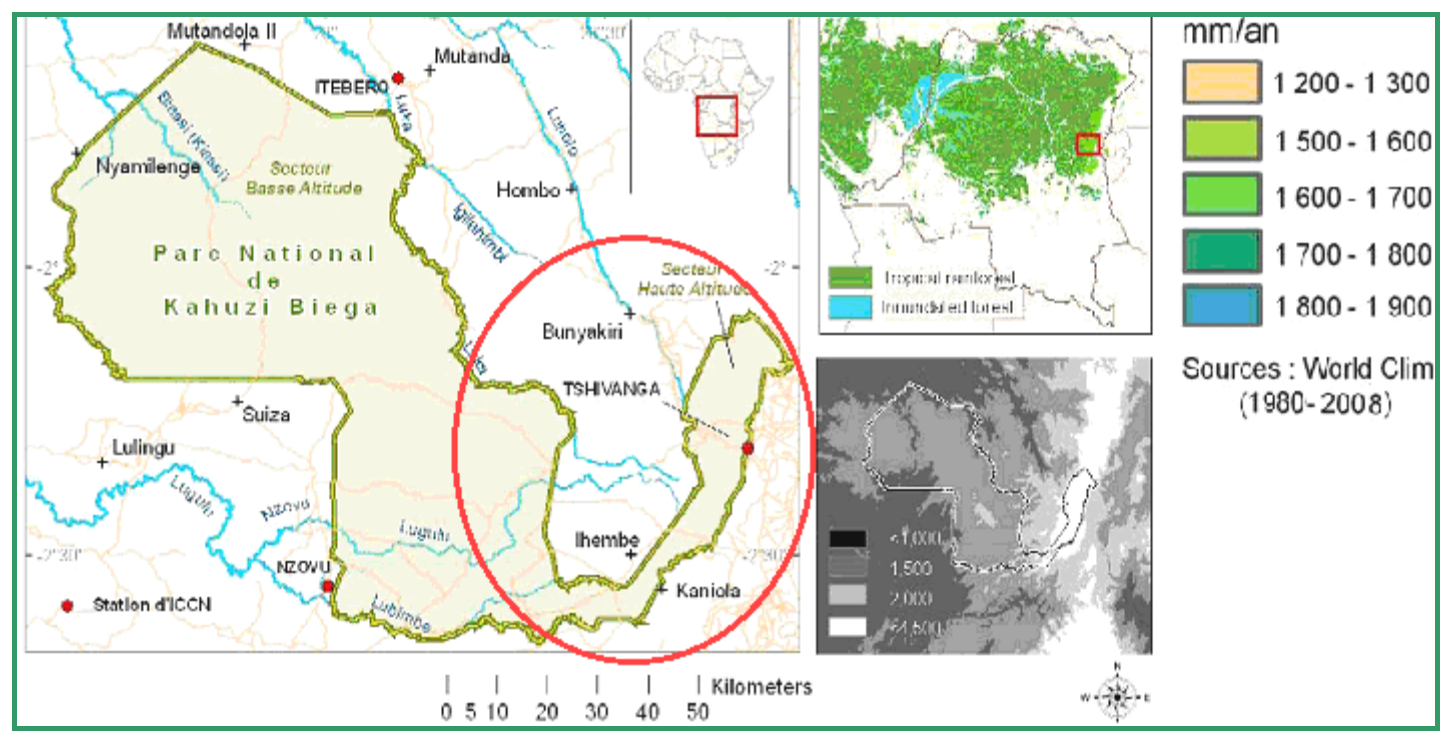

Fig. 1: Map of Kahuzi-Biega National Park, « Part encircled "2/6, $\pm 2400 \mathrm{~km}$ 'study area». Source (Amisi et al., 2008). 
According to their physiognomy and floristic composition, depending on the altitude, lowland forests, KBNP is divided into many parts $(678-1250 \mathrm{~m})$, submontainous, (1250-1700 m), mountain (1700-2600 $\mathrm{m})$ and Afro-alpine (2600-3326 m).

Overall, the area has a mountain climates (Cf of type Köppen), with heavy rainfall, ranging from 1750 to 2000 $\mathrm{mm}$ per year (Mangambu, 2013). Climate at Mount Kahuzi is characterised by night frosts, an expression of Afro-alpine type with every summer day and every winter night (Fischer, 1996). The humidity is constantly high parallel to the change in cloud cover. The length of the dry season does not exceed two months. The temperature varies with altitude and the soil is shallow and acid (Mangambu, 2013).

\section{Materials}

Two species of Asplenium from Kahuzi-Biega National Park were sequenced using TRNG, RPS4 and trnL-FtrnS markers. The obtained sequencing was incorporated into an already existing data set from the works of Schneider et al. (2004) and Matos et al. (2009). The samples used in this study are presented in Tables 1 and 2.

Table 1. Sample list of species Asplenium aethiopicum.

\begin{tabular}{llllll}
\hline $\mathbf{N}^{\circ}$ & Species Name & Collection of herbarium & trnG & Rps4-trnS & trnL-F \\
\hline 1 & Asplenium aethiopicum & Mangambu 2966 & + & + & + \\
2 & Asplenium aethiopicum & Mangambu 2996 & + & + & + \\
3 & Asplenium aethiopicum & Mangambu 3068 & + & + & + \\
4 & Asplenium aethiopicum & Mangambu 3146 & + & + & + \\
5 & Asplenium aethiopicum & Mangambu 2928 & + & + & + \\
6 & Asplenium aethiopicum & Mangambu 3024 & + & + & + \\
7 & Asplenium aethiopicum & Mangambu 3067 & + & + & + \\
8 & Asplenium aethiopicum & Mangambu 2900 & + & + & + \\
9 & Asplenium aethiopicum & Mangambu 2892 & - & + & - \\
10 & Asplenium aethiopicum & Mangambu 2938 & + & + & + \\
11 & Asplenium aethiopicum & Mangambu 3067b & + & + & + \\
12 & Asplenium aethiopicum & Mangambu 2704b & - & - & - \\
13 & Asplenium aethiopicum & Mangambu 2941 & + & - & + \\
14 & Asplenium aethiopicum & Mangambu 2704 & + & + & + \\
15 & Asplenium aethiopicum & Mangambu 3035 & - & - & - \\
\hline
\end{tabular}

Table 2. Sample list of species Asplenium friesiorum and affinity (complex)

\begin{tabular}{llllll}
\hline $\mathbf{N}^{\circ}$ & Species Name & Collection of herbarium & trnG & Rps4-trnS & trnL-F \\
\hline 1 & Asplenium friesiorum & Mangambu 2874 & + & + & + \\
2 & Asplenium complex & Mangambu 2887 & + & + & + \\
3 & Asplenium complex & Mangambu 2947 & + & + & + \\
4 & Asplenium complex & Mangambu 2970 & + & + & + \\
5 & Asplenium friesiorum & Mangambu 3129 & + & + & + \\
6 & Asplenium friesiorum & Mangambu 3145 & + & + & + \\
7 & Asplenium friesiorum & Mangambu 3158 & + & + & + \\
8 & Asplenium complex & Mangambu 2860 & + & + & + \\
9 & Asplenium complex & Mangambu 3033 & + & + & + \\
10 & Asplenium friesiorum & Mangambu 2970b & + & + & + \\
11 & Asplenium friesiorum & Mangambu 3189 & + & + & + \\
12 & Asplenium friesiorum & Mangambu 2698 & + & + & + \\
13 & Asplenium complex & Mangambu 2332 & + & + & + \\
14 & Asplenium complex & Mangambu 2002 & + & + & + \\
15 & Asplenium complex & Mangambu 2197 & + & + & + \\
\hline
\end{tabular}

Laboratory analyzes

Molecular phylogenetic: DNA extraction, amplification and sequencing technique were performed following
Schneider et al. (2004a). DNA was extracted from 27 samples (sheets) including 12 samples for A. friesiorum C.Chr (and affinity), 15 samples for A. aethiopicum (Burm.f.) Bech. dried in silica gel. The samples were 
grouped into 2 sets of different morphotypes. Consensus sequences were assembled by Sequencher $4.8 \AA$ software (Gene Code Cooperation) and all sequences comprising taxa in group and out group (Table 3) were aligned manually due to their low variation, using Mac Clade 4.0.8 software (Maddison and Maddison, 2005).

Table 3. List of cp DNA loci tested and the corresponding primers (Schuettpelz and Pryer, 2007).

\begin{tabular}{|c|c|c|}
\hline \multirow{2}{*}{$\begin{array}{l}\text { Loci } \\
\text { trnL-F }\end{array}$} & Amorces & \\
\hline & Fern1 (Foward) & -GGCAGCCCCCARATTCAGGGRAACC \\
\hline & $T F-R$ (Reverse) & -ATTTGAACTGGTGACACGAG \\
\hline rps4-trnS & rps4-trnS-F (Foward) & -ATGTCMCGTTAYCGAGGRCCTCGT \\
\hline & rps4-trnS-R (Reverse) & -TACCGAGGGTTCGAATC \\
\hline $\operatorname{trn} G$ & $\operatorname{trnGlF}$ (Foward) & -GCGGGTATAGTTTAGTGGTAA \\
\hline & $\operatorname{trnR} 22 R$ (Reverse) & -CTATCCATTAGACGATGGACG \\
\hline
\end{tabular}

Analysis of spores: To strengthen the results, all samples were examined for phylogenetic analyzes spores of samples of the present study. Spores of species were removed from herbarium specimens (Table 1 and 2) and subjected to a three step process. The initial step consisted in placing the spores inside $1.5 \mathrm{ml}$ microtubes with $70 \%$ ethanol. This initial treatment was followed by placing the microtubes inside an ultrasonic wave bath (1510 BRANSON, 50-60Hz, 90W) for $10 \mathrm{~min}$. This second step was followed by 4 min. centrifugation (6000 rpm). This three steps protocol was repeated three times, each washing step (70\% ethanol) required a resuspension of the pellet of spores. Subsequent to this treatment, the spores and washing $70 \%$ ethanol solution were transferred to a double sided adhesive tape with a micro-pipette. Once the $70 \%$ ethanol solution vaporized the dried spores were gold coated using standard electron microscopy techniques. These samples were subsequently observed and photographed under a Hitachi JSM-6360LV Scanning Electron Microscope. Untreated spores were compared to the ones that were prepared following the protocol presented in this study.

\section{Data analysis}

Before analyzing a concatenated chloroplast data matrix, each marker was analyzed separately in order to visually recognize putative phylogenetic differences between the different chloroplast datasets. A partition homogeneity test (implemented in PAUP* 4.0b10a; Swofford 2002) was carried out to statistically detect whether the data matrices provided different phylogenetic signal.

The best performing substitution model for Maximum Likelihood (ML) and Bayesian Inference (BI) was determined for each locus using the Akaike Information Criterion (AIC) as implemented in ModelTest 3.06 (Posada and Crandall, 1998). For each dataset, the AIC suggested the GTR+G model.
Bayesian analyses of either single chloroplast markers or concatenated dataset were conducted with MrBayes 3.1 (Huelsenbeck and Ronquist, 2001; Ronquist and Huelsenbeck, 2003). Two runs of four chains (one cold, three heated), initiated from a random starting tree, were monitered for two million generations at which stationary was reached. Every 100 generations, a tree was sampled from the chain for a total of 20,000 trees.

Convergence of the runs was checked by Tracer 1.5 . (Drummond and Rambaut, 2007) resulting in a removal of 5,000 sample points due to burn-in. Geneious v 5.4.6 was used to compute the $50 \%$ majority rule consensus tree. Maximum Likelihood analyses were carried out using the RAxML search algorithm (Stamatakis et al., 2005) under the GTRGAMMA approximation of rate heterogeneity for each gene (Stamatakis, 2006) as implemented in RAxML 7.2.8. Five hundred bootstrap trees were inferred using the RAxML Rapid bootstrap algorithm to provide support values for the best-scoring ML tree.

\section{Results and discussion}

\section{Phylogenetic inference}

Single-gene phylogenies revealed no phylogenetic discrepancies, and also the partition homogeneity test $(P>0.05)$ did not show any conflict between the different chloroplast data sets. As a result, we combined all data sets for further phylogenetic analysis. The concatenated data set consisted of 84 species and 3143 analyzed characters (rps4-trnS: 1056 bp; trnL-F: $1057 \mathrm{bp}$; trnG: 1030 bp). ML analysis provided a less supported phylogeny of Asplenium compared to Bayesian analysis, which generated in general moderate to high support values (Fig. 2). No conflict was found however between both phylogeny reconstruction methods (Fig. 2). The relationships within Asplenium L. are highly congruent 
with those described in previous phylogenetic analyses (Murakami et al., 1999; Herman et al., 2003; van den Heede et al., 2003, Schneider et al. 2005). Although the backbone of the Asplenium phylogeny is only weak to moderately supported, the majority of the recently diversified lineages show high support value, as is the case for the clade to which Asplenium aethiopicum (Burm.f.) Bech. and A. friesiorum C.Chr belong.

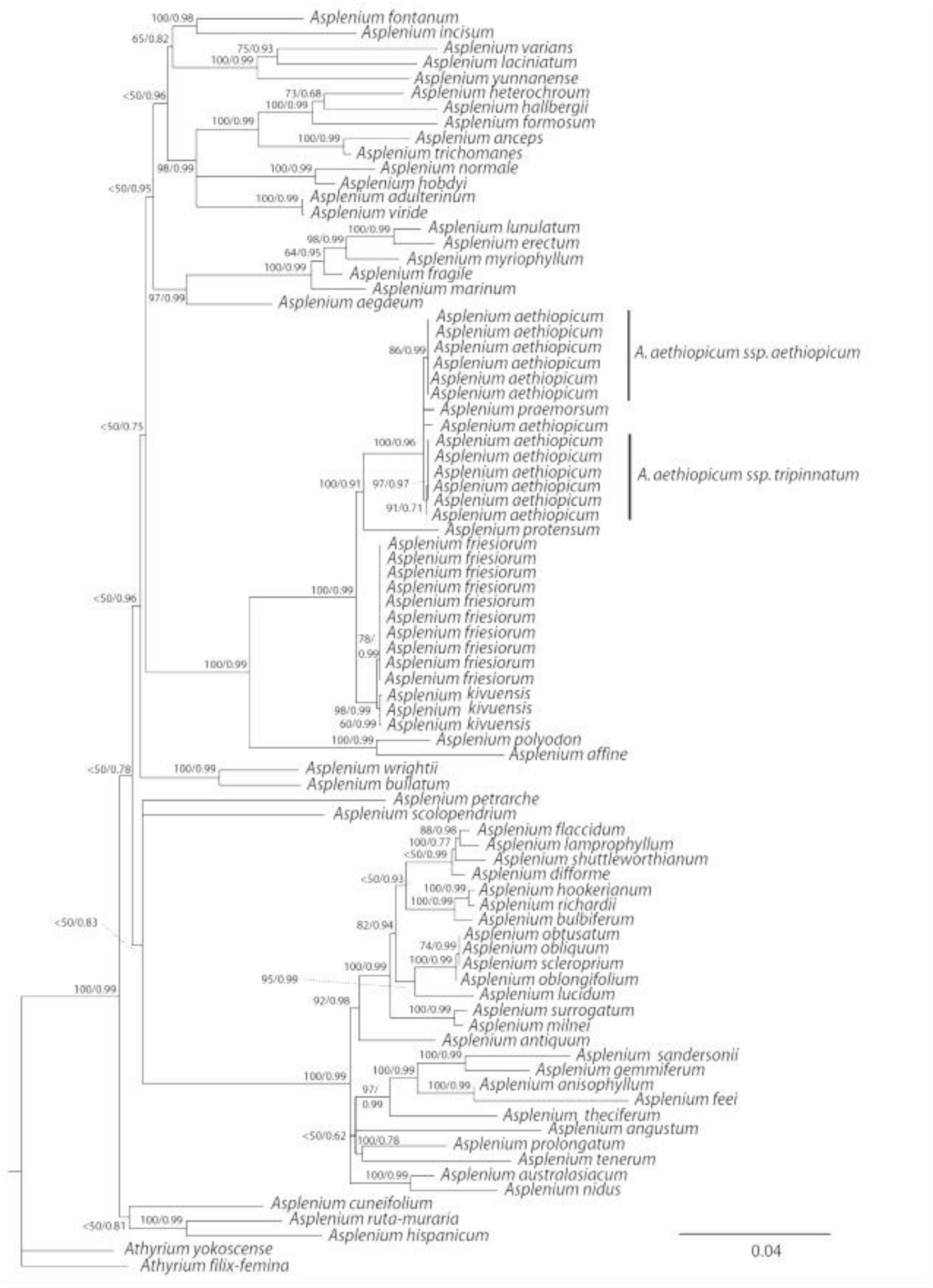

Fig. 2: Consensus phylogenetic tree from two methods (Maximum Likelihood and Bayesian analysis). 
Both $\mathrm{ML}$ and $\mathrm{BI}$ indicate that the well supported sister species A. polyodon G. Forster and A. affine Sw. (ML: 100, BI: 0.99) are sister to a clade containing $A$. friesiorum C.Chr., A. protensum Schrad., A. aethiopicum (Burm.f.) Bech. and A. praemorsum sensu Sim (ML: 100, BI: 0.99). In addition, A. friesiorum C.Chr. is sister to A. protensum Schrad., A. aethiopicum (Burm.f.) Bech. and $A$. praemorsum sensu Sim (ML: 100, BI: 0.99), whereas A. protensum Schrad. is the sister species of a polytomy consisting of A. aethiopicum (Burm.f.) Bech. and $A$. praemorsum sensu Sim (ML: 100, BI: 0.91). Within the clade containing A. aethiopicum (Burm.f.) Bech. and A. praemorsum sensu Sim (ML: 100, BI: 0.96), three main groups can be delined:

- A. praemorsum sensu Sim (single specimen),

- A. aethiopicum (Burm.f.) Bech. ssp. aethiopicum (ML: 86, BI: 0.99) and

- A. aethiopicum (Burm.f.) Bech. ssp. Tripinnatum (Baker) A.F.Braithw (ML: 97, BI: 0.97).

Furthermore, the lineage containing specimens of $A$. friesiorum C.Chr. (ML: 98, BI: 0.99) also consist of two clearly delimited clades, A. friesiorum C.Chr. (ML: 78, BI: 0.99) and A. friesiorum kivuensis Mangambu nov.* (Fig. 3) (ML: 60, BI: 0.99).
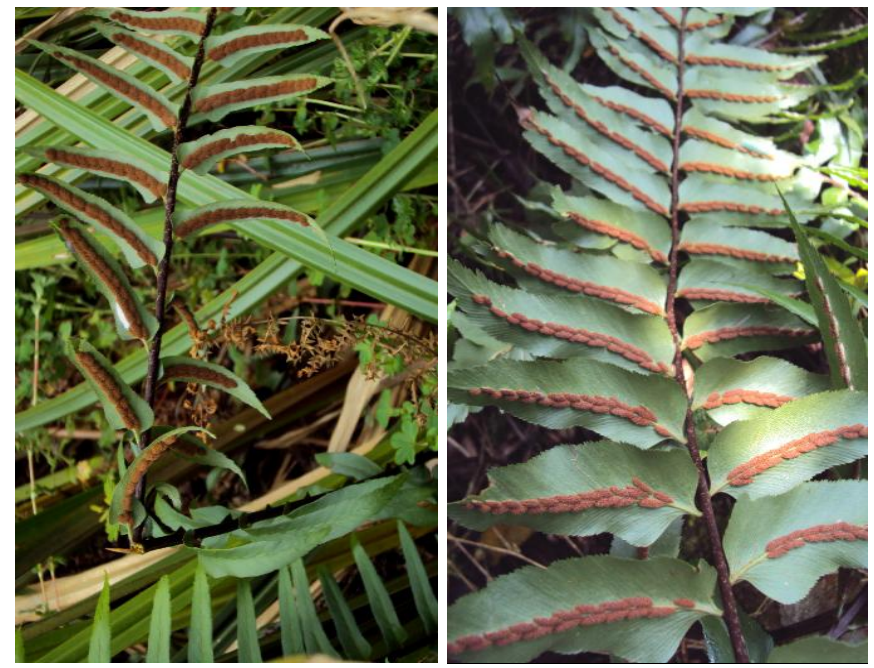

Fig. 3: Fern of Kahuzi-Biega National Park: Asplenium kivuensis (photo: Mangambu).

\section{Molecular markers}

The markers used for chloroplast phylogenetic test of Aspleniaceae appear to result into sequences that vary from one group to another. It appears that there are no markers used in a consensual manner. The use of a marker depends on the taxonomic level of plants from which the investigations are carried out, the easiness it provides for its amplification and finally the ability to discriminate (Hasebe et al., 1994 and 1995; Schneider et al., 2005; de Groot et al., 2011). The chloroplast gene $\operatorname{trn} G$ is widely and commonly used in phylogenetic investigations at the species and higher level of Asplenium taxa. This is due to the fact that it evolves slowly, and it detects changes in the sequences (Schneider et al., 2005). Several authors (Hasebe et al., 1995; Testo and Watkins, 2011; Regalado and Carmen, 2011) approved its use. Strategy to increase the resolution of the trees is to involve non- coding intergenic regions, trnG. These regions have the advantage of not undergo selection, rapidly evolving and highly polymorphic. The Markers rps4-trnS have not only increased the chance of amplification and discrimination (Singh and Bir, 1989) of the studied chloroplast data, but also compared and confirmed our results. The works of Schneider et al. (2005) also suggested the use of these three markers to further confirm the results and draw more conclusions regarding the time of divergence of these copies and Aspleniaceae phylogenetic signal. During the present study, we found that both markers have facilitated the amplification of sequences and have a greater ability to discrimination.

\section{Taxonomic position of the studied subspecies and species}

Based on morphological characters, the three species of Asplenium (A. aethiopicum (Burm.f.) Bech., A. friesiorum C.Chr and affinity of A. friesiorum C.Chr) were classified in different sections (Mangambu, 2013). The taxonomic position of the two species within Aspleniaceae shows for each species, two different subspecies (Tables 4 and 7).

\section{Key to the subspecies}

1 Fronds up to 1,25 m long, 3-pinnate; basis of pinna asymmetrical, slightly more widely spaced, firmly herbaceous, lanceolate; sori more per lobe, closely packed along the veins subsp. tripinnatum

- Fronds up to $600 \mathrm{~mm}$ long; 2-pinnate to 2-pinnate-pinnatifid; pinnae trullate with usually more than 3 free pinnules, basis of pinna more or less cordate or sometimes round or wedge; Sori linear, extending along a vein subsp. aethiopicum 
Regarding the two sub- species A. aethiopicum (Burm.f.) Bech., we conducted analyzes to find and explain the great morphological similarity between these two species, which often leads to confusion in identification. Several authors (Matos et al., 2009; Ledis and Carmen, 2011) argue that the biological species concept is widely used in the identification of subspecies of Asplenium aethiopicum (Burm.f.) Bech. roughly corresponding to four or six subspecies in Africa (Roux, 2001). For the two subspecies of Asplenium aethiopicum (Burm.f.) Bech. studied spores microscopic observations show the differences in shape and size (Table 5). A morphological construction $A$. aethiopicum (Burm.f.) Bech. subsp. aethiopicum is reniform in lighter shade while A. aethiopicum (Burm.f.) Bech. subsp. tripinnatum (Baker) A.F.Braithw spore is a little less clear subellipsoïdale color (Fig. 4).

But looking at the phylogenetic tree (Fig. 2), we found that between the two subspecies of A. aethiopicum there is another species A. praemorsum. This species is considered to some authors as a subspecies of $A$. aethiopicum (Lawesson et al., 1987) and the name of $A$. praemorsum does apply to American plants rarely spotted in Africa. Other authors (Mickel and Beitel, 1988; Mickel and Smith, 2004) think it is a different species than A. aethiopicum.

Table 4. Main distinctive characters of the subspecies of Asplenium aethiopicum (Burm.F.) Bech.

\begin{tabular}{|c|c|c|}
\hline Characters & $\begin{array}{l}\text { Asplenium aethiopicum (Burm.F.) Bech. } \\
\text { aethiopicum }\end{array}$ & $\begin{array}{l}\text { Asplenium aethiopicum (Burm.F.) Bech.subsp. } \\
\text { tripinnatum (Baker) A.F.Braithw }\end{array}$ \\
\hline Rhizome & Crawling or near upright, & Short-creeping, sparsely branched, short, \\
\hline Fronds & $\begin{array}{l}\text { Closely spaced, arching } \\
45-97 \mathrm{~cm} \text { long. }\end{array}$ & $\begin{array}{l}\text { closely spaced, arching, to } 78-1.12 \mathrm{~cm} \text { long; } \\
\text { stramineous. }\end{array}$ \\
\hline Stipe & $\begin{array}{l}\text { Stipe firm, atrocastaneus to black, adaxially } \\
\text { sulcate, covered with scales blackish } \\
\text { ferruginous. }\end{array}$ & $\begin{array}{l}\text { Atrocastaneus, adaxially sulcate, densely scaled } \\
\text { initially, scales chartaceus, atrocastaneus to } \\
\text { ferrugineous, clathrate, sessile, subulate to filiform, } \\
\text { cordate-imbricate, entire or shallowly dentate. }\end{array}$ \\
\hline Lamina & $\begin{array}{l}\text { Not anadromous, 3-pennatifide, 2-pinnate to the } \\
\text { base, narrowly elliptic to lanceolate. }\end{array}$ & $\begin{array}{l}\text { Anadromous, to 3-pinnate, narrowly elliptic to } \\
\text { lanceolate, glabrous or narrowly elliptic, triangular }\end{array}$ \\
\hline Pinnae & $\begin{array}{l}\text { Petiolate, opposite to alternate, basally slightly } \\
\text { more widely spaced, firmly herbaceous, } \\
\text { lanceolate. }\end{array}$ & petiolate, opposite another oval-elliptic deltoid. \\
\hline Basis of pinna & $\begin{array}{l}\text { Asymmetrical, slightly more widely spaced, } \\
\text { firmly herbaceous, lanceolate. }\end{array}$ & More or less cordate or sometimes round or wedge. \\
\hline Pinnule & $\begin{array}{l}\text { Cuneate, irregularly dentate, to } 25 \mathrm{~mm} \text { long, } \\
\text { trullate or obtrullate, narrowly to broadly } \\
\text { cuneate, basiscopically decurrent towards the } \\
\text { apex, divided into oblong segments. }\end{array}$ & $\begin{array}{l}\text { Irregularly dentate, to } 10 \mathrm{~mm} \text { long, to } 8 \mathrm{~mm} \text { wide, } \\
\text { adaxially sparsely scaled, scales chartaceus, } \\
\text { ferrugineous, clathrate, sessile, petiolate, petiole to } 2 \\
\text { mm long, alternate, spaced, } 1 \text {-pinnate, trullate to } \\
\text { narrowly trullate, to } 33 \mathrm{~mm} \text { long. }\end{array}$ \\
\hline Sori & $\begin{array}{l}\text { More per lobe, closely packed along the veins, } \\
\text { to } 2.5-8.5 \mathrm{~mm} \text { long; indusium firmly } \\
\text { herbaceous, stramineous, entire, attached along } \\
\text { the entire length, to } 8.5 \mathrm{~mm} \text { long, to } 0.3 \mathrm{~mm} \\
\text { wide. }\end{array}$ & $\begin{array}{l}\text { Linear, extending along a vein, to } 5-12,6 \mathrm{~mm} \text { long; } \\
\text { indusium firmly herbaceous, stramineous, linear, } \\
\text { entire, attached along the entire length, to } 5 \mathrm{~mm} \\
\text { long, to } 0.3 \mathrm{~mm} \text { wide; sporangium long-stalked, } \\
\text { simple, uniseriate, } 3 \text {-seriate below the capsule. }\end{array}$ \\
\hline $\begin{array}{l}\text { Habitats } \\
\text { and ecology }\end{array}$ & $\begin{array}{l}\text { Terrestrial, epilithic or low-level epiphyte, moist } \\
\text { or seasonally moist forests, forest remnants and } \\
\text { rocky outcrops, partially shaded, 50-1800 m. }\end{array}$ & $\begin{array}{l}\text { Terrestrial, occasional in moist or seasonally moist } \\
\text { forests and forest remnants, shaded, 50-2 } 600 \mathrm{~m} \text {. }\end{array}$ \\
\hline Distribution & $\begin{array}{l}\text { Bioko, Burundi, Cameroon, Central African } \\
\text { Republic, Congo, Democratic Republic of the } \\
\text { Congo, Ethiopia, Gabon, Guinea, Kenya, } \\
\text { Liberia, Malawi, Mozambique, Nigeria, } \\
\text { Rwanda, São Tomé, Sierra Leone, Somalia, } \\
\text { South Africa, Swaziland, Tanzania, Uganda and } \\
\text { Zimbabwe }\end{array}$ & $\begin{array}{l}\text { Burundi, Democratic Republic of the Congo, } \\
\text { Mozambique, South Africa, Swaziland and } \\
\text { Zimbabwe. }\end{array}$ \\
\hline
\end{tabular}


Table 5. Statistical results of the two subspecies of Asplenium aethiopicum (Burm.F.) Bech.

\begin{tabular}{|c|c|c|c|c|c|}
\hline \multicolumn{3}{|c|}{ Asplenium aethiopicum (Burm.F.) Bech. aethiopicum } & \multicolumn{3}{|c|}{$\begin{array}{l}\text { Asplenium aethiopicum (Burm.F.) Bech. subsp. } \\
\text { tripinnatum (Baker) A.F.Braithw }\end{array}$} \\
\hline Statistical function & ID & Line length & Statistical function & ID & Line length \\
\hline Base unit & & $\mu \mathrm{m}$ & Base unit & & $\mu \mathrm{m}$ \\
\hline Count & 12 & 12 & Count & 12 & 12 \\
\hline Mean & 6.5 & 167.84 & Mean & 6.5 & 40.71 \\
\hline Minimum & 1 & 150.05 & Minimum & 1 & 34.61 \\
\hline Standard Deviation & 3.61 & 10.32 & Standard Deviation & 3.61 & 4.25 \\
\hline
\end{tabular}

They think that African plants have morphology of the lamina and pinnae somewhat different and are maintained, including Mickel and Smith (2004) in A. aethiopicum represents a complex study. Braithwaite (1986) had been a synonym of $A$. praemorsum sensu., but the current data are that these two taxa are considered separate (Singh and Bir,
1989; Nripemo et al., 2012). In the present study we cannot establish the relations between the two species by lack of phylogenetic information on $A$. praemorsum sensu. Nevertheless, in some cases, the genomic molecular relation does not match the morphological combinations (Hasebe et al., 1994 and 1995).

Table 6. Main distinctive characters of the species of Asplenium friesiorum C.Chr. and its affinity (A. kivuensis Mangambu nov.*)

\begin{tabular}{|c|c|c|}
\hline Characters & Asplenium friesiorum C.Chr. & Asplenium kivuensis Mangambu Nov.* \\
\hline Rhizome & Creeping, short or long. & Dictyostelic, creeping, suberect. \\
\hline Fronds & $\begin{array}{l}\text { Frond fronds widely spaced; erect, not proliferous, thinly } \\
\text { coriaceous, widely spaced, curved, } 55-98 \mathrm{~cm} \text { long, not } \\
\text { proliferous, 56-196 (200) cm long with pinnae. }\end{array}$ & $\begin{array}{l}\text { Dense, close, straight and reaching } 88-150 \mathrm{~cm} \text { in length, } \\
\text { not proliferous, 36-162 (172) } \mathrm{cm} \text { long with pinnae. }\end{array}$ \\
\hline Stipe & $\begin{array}{l}\text { Dull-brown or purplish-brown, up to } 36-77 \mathrm{~cm} \text {. long, set } \\
\text { with brown lanceolate to ovate small scales similar to } \\
\text { those on the rhizome, } 8-17 \mathrm{~cm} \text { long. }\end{array}$ & $\begin{array}{l}\text { Sometimes glabrescent presence of a few scattered } \\
\text { scales on basal part, } 15-30 \mathrm{~cm} \text { long, set with brown } \\
\text { lanceolate to ovate small scales similar to those on the } \\
\text { rhizome, } 8-17 \mathrm{~cm} \text { long. }\end{array}$ \\
\hline Lamina & $\begin{array}{l}\text { Membranous, Browning, the terminal segment pointed, } \\
\text { wavy, pennatilobe, pinnae } 13-33 \text { pairs, alternate or } \\
\text { subopposite. }\end{array}$ & $\begin{array}{l}\text { Narrowed at the top, the terminal segment deltoid lobed } \\
\text { toothed pennatifide, Pinnae } 6-12 \text { pairs, opposite, dark } \\
\text { green above. }\end{array}$ \\
\hline Sori & $\begin{array}{l}\text { Elongate as a chain or sometimes two small lines in the } \\
\text { rib to } 2 / 5 \text { or } 3 / 5 \text {, usually many, oblong, } 3-7(9) \mathrm{mm} \text { long, } \\
1-3 \mathrm{~mm} \text { wide at maturity. }\end{array}$ & $\begin{array}{l}\text { Two lines to the top near the costa, but slightly oblique } \\
\text { right on the rib until } 4 / 5 \text {, usually many, oblong, } 12-15 \\
\text { (17) } \mathrm{mm} \text { long, } 3-5 \mathrm{~mm} \text { wide at maturity. }\end{array}$ \\
\hline $\begin{array}{l}\text { Ecology } \\
\text { and habitats }\end{array}$ & $\begin{array}{l}\text { Terrestrial or epilithic, in moist evergreen Forests or } \\
\text { among boulders in montane grassveld, exposed or deeply } \\
\text { shaded, } 78-3324 \mathrm{~m} \text {. }\end{array}$ & $\begin{array}{l}\text { Terrestrial or epilithic, in moist deeply shaded forests, } \\
1021-2332 \mathrm{~m} \text {. }\end{array}$ \\
\hline Distribution & $\begin{array}{l}\text { Angola, Bioko, Burundi, Cameroon, Congo, Democratic } \\
\text { Republic of the Congo, Ethiopia, Kenya, Malawi, } \\
\text { Mozambique, Nigeria, Rwanda, São Tomé, South Africa, } \\
\text { Sudan, Tanzania, Uganda, Zambia and Zimbabwe. Also in } \\
\text { the Madagascan region. }\end{array}$ & Kahuzi-Biega National Park mountain (D R. Congo) \\
\hline
\end{tabular}

\section{Key to the species}

1. Rhizome creeping; fronds widely spaced; thinly coriaceous, widely spaced, curved, 55-98 cm long, 56-196 (200) cm long with pinnae, sori borne close to the costa. A. friesiorum

Rhizome erect, creeping, dense, close, straight and reaching 88-150 cm in length, not proliferous, 36-162 (172) cm long with pinnae, two lines to the top near the costa.... A. kivuensis 


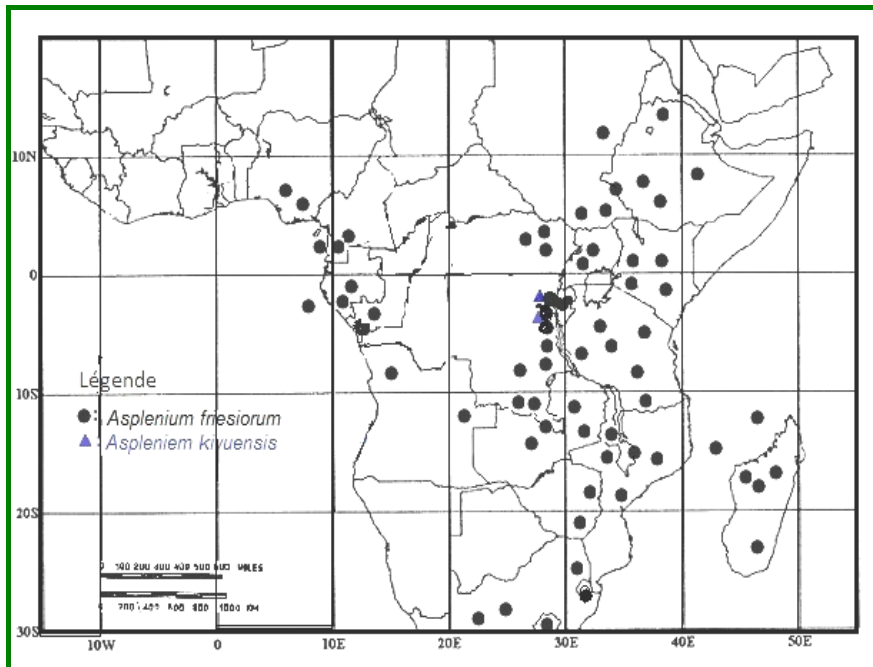

Fig. 4: Distribution map of Asplenium kivuensis Mangambu nov.*

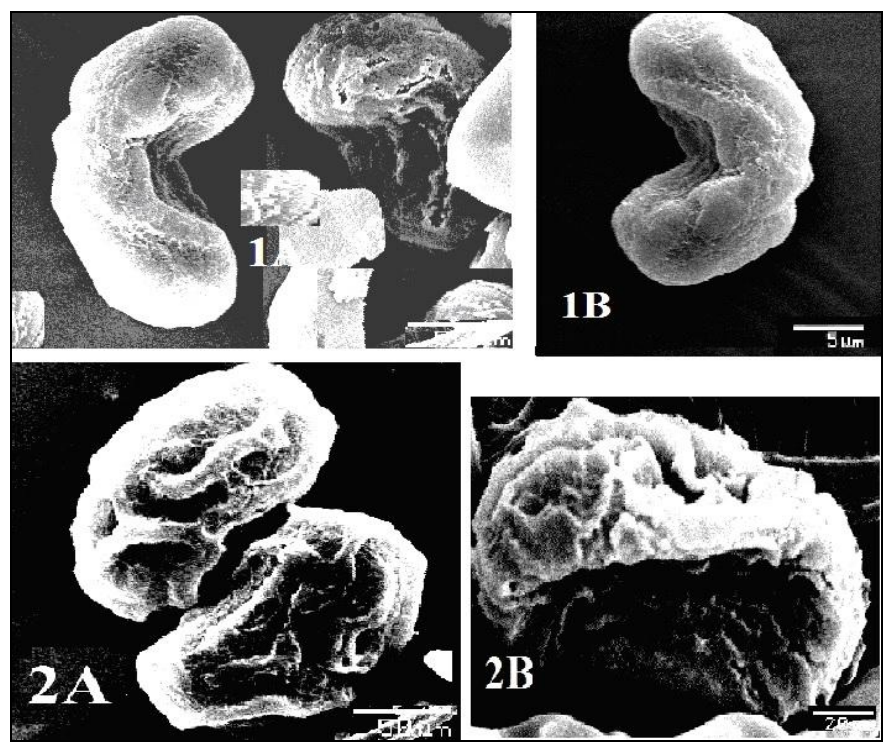

Fig. 5: Images M.E.B. original showing the difference of the input spores under both species Asplenium aethiopicum harvested from PNKB (1 A. aethiopicum aethiopicum subsp.. 1A: all spores sporangium, 1B: an isolated spore, and 2 A. aethiopicum subsp.. tripinnatum: 2A: set of two spores within the sporangium, 2B: an isolated spore Measure: 1A, 2A, bar: 50 microns; 1B and 2B Bar. 2 microns.
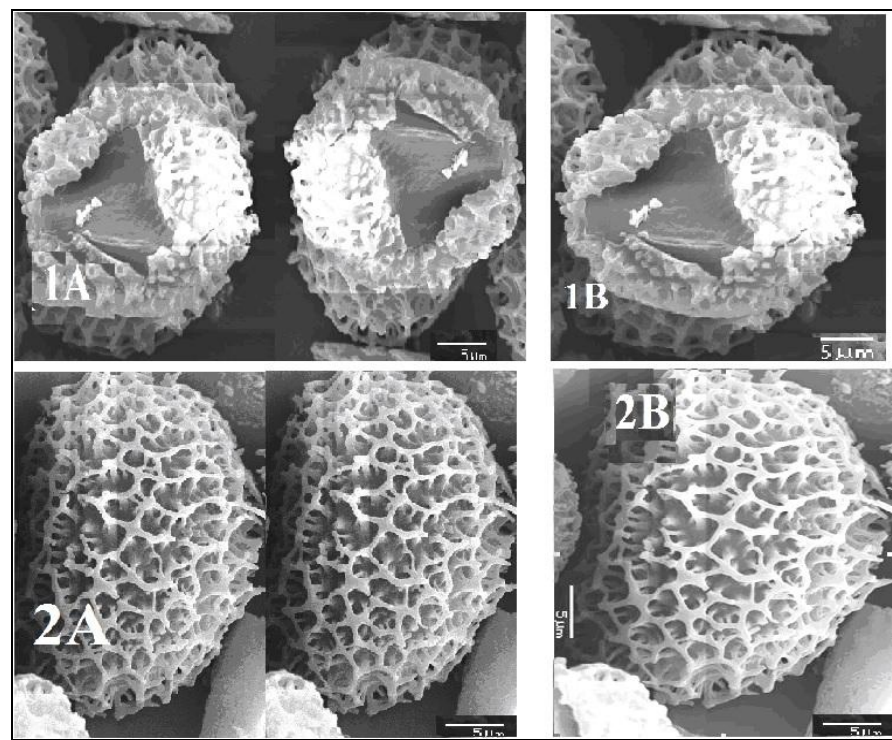

Fig. 6: Images M.E.B. original showing the difference of the input spores under both species Asplenium friesiorum and affinity harvested PNKB. 1 A. kivuensis Mangambu nov.* 1A: all spores in the sporangium, 1B: an isolated spore, and $2 A$. friesiorum. 2A: all spores within sporangia, 2B: isolated spore Measure: 1A, 2A, Bar: 10 $\mu \mathrm{m}$; $1 \mathrm{~B}$ and 2B Bar: $5 \mu \mathrm{m}$.

Typus of Asplenium kivuensis Mangambu nov.*: Mangambu 2947 (BR, LWI): Tshibati (S215319, E2847376), 1914 m, harvested 7 July 2011 (holo-, BR!; iso-, LWI!).

The distribution map of A. kivuensis Mangambu nov.* is shown in Fig. 4. The phylogenic tree (Fig. 2) obtained from the consensus between several taxa of the genus Asplenium showed a strong correlation between the morphological and molecular criteria. The observation clearly demonstrates that there is a new subspecies of $A$. friesiorum C.Chr. This is further confirmed by the microscopic analyses of spores using screening (sweeping) electronic microscopy (Table 7). The spore of A. kivuensis Mangambu nov.* (Fig. 5) is more or less ellipsoïdal and hollow inside with more or less dark colour; while A. friesiorum C.Chr has an ovoid spore, with less clear tint (Fig. 6).

Table 7. Statistical results of the two subspecies of Asplenium friesiorum C.Chr. and its affinity (A. kivuensis Mangambu nov.*)

\begin{tabular}{|c|c|c|c|c|c|}
\hline \multicolumn{3}{|c|}{ Asplenium friesiorum C.Chr. } & \multicolumn{3}{|c|}{ Asplenium kivuensis Mangambu Nov.* } \\
\hline Statistical function & ID & Line length & Statistical function & ID & Line length \\
\hline Base unit & & $\mu \mathrm{m}$ & Base unit & & $\mu \mathrm{m}$ \\
\hline Count & 5 & 5 & Count & 5 & 5 \\
\hline Mean & 3 & 28.08 & Mean & 3 & 97.98 \\
\hline Minimum & 1 & 22.18 & Minimum & 1 & 80.9 \\
\hline Maximum & 5 & 33.69 & Maximum & 5 & 108.38 \\
\hline Standard deviation & 1.58 & 5.03 & Standard deviation & 1.58 & 9.38 \\
\hline
\end{tabular}




\section{Conclusions}

This study has established the existence of two subspecies in each of Asplenium species analyzed. In the present study we wanted to involve both a molecular markers most commonly used in phylogenetic studies of Pteridophyta $(\operatorname{trn} G)$ and two others $(\operatorname{trn} L-F$ and $r p s 4$ $t r n S$ ) having relatively high discriminative power at intra - specific and wearing more substantial genetic information.

The results combine morphological and molecular analyzes. Unfortunately, this study will not be possible to establish the relationship between the two subspecies of the species A. aethiopicum and A. praemorsum. It will be necessary to collect Asplenium praemorsum populations in silica and consider another study and phylogenetic analysis to incorporate the data in the present results and also provide analysis of combined molecular and morphological data. If possible, we should add other species of Asplenium of our region or geographically distant representatives for each analysis.

\section{Conflict of interest statement}

Authors declare that they have no conflict of interest.

\section{Acknowledgement}

The results of this study have been achieved thanks to financial supports from the Belgian Technical Cooperation (BTC), National Botanic Garden of Belgium (JBN) and United Nations Educational, Scientific and Cultural Organization (UNESCO). We are thankful to the Kahuzi-Biega National Park (KBNP) for their cooperation and hospitality during field works. Special thanks are addressed to everyone who took an active part in the data collection campaign.

\section{References}

Amisi, F., Ilambu, O., Liengola, I., Kujirakwinja, D., Hart, J., Grossman, F., Plumptre, A., 2008. The impact of the wars on Kahuzi-Biega National Park. Results of surveys between 2000-2008. Unpublished report, Wildlife Conservation Society, 1-31.

Braithwaite, A. F., 1986. The Asplenium aethiopicum complex in South Africa. J. Linn. Soc. 93, 343-378.

de Groot G. A., During, H. J., Maas, J. W., Schneider, H., Vogel, J. C., Erkens, R. H., 2011. Use of $r b c L$ and $t r n L-F$ as a two-locus DNA barcode for identification of NWEuropean ferns: an ecological perspective. PLoS One. 6, 216-371.
Drummond, A.J., Rambaut, A., 2007. BEAST: Bayesian evolutionary analysis by sampling trees. BMC Evol. Biol. 7, 1-214.

Fischer, E., 1996. Die Vegetation des Parcs National de Kahuzi-Biega, Sud-Kivu, Zaïre. Franz Steiner Verlag. Stuttgart, 1-239.

Gastony, G., Johnson, W., 2001. Phylogenetic placements of Loxoscaphe thecifera (Aspleniaceae) and Actiniopteris radiata (Pteridaceae) based on analysis of $r b c L$ nucleotide sequences. J. Amer. Fern J. 91(4), 197-213.

Hasebe, M., Oumori, T., Nakazawa, M., Iwatsuki, K., Kato, M., 1994. $r b c L$ gene sequences gave new clue to evolutionary lineage for leptosporangiate ferns. Proc. Nat. Acad. Sci. USA. 91, 5730-5734.

Hasebe, M., Wolf, P., Pryer, K., Ueda, K., Ito, M., Sano, R., Gastony, G., Yokoyama, J., Manhart, J., Murakami, N., Crane, E., Haufler, C., Hauk, W., 1995. Fern phylogeny based on $r b c L$ nucleotide sequences. Am. Fern J. 85, 134181.

Huelsenbeck, J., Ronquist, F., 2001. MRBAYES. Bayesian inference of phylogeny. Bioinfor. 17, 754-755.

Iwatsuki, K., 1984. Studies in the systematics of filmy ferns. VII. A scheme of classification based chiefly on the Asiatic species. Acta Phytotaxon. Geobotan. 35, 165-179.

Kramer, K. U., Viane, R. L. L., 1990. Aspleniaceae. In: Pteridophytes and Gymnosperms (Eds.: Kramer, K. U., Green, P. S.). Springer-Verlag, Berlin. pp.52-56.

Lawesson, J. E., Adsersen, H., Bentley, P., 1987. An updated and annotated check list of the vascular plants of the Galapagos Islands. Botanisk Inst. Aarhus Univer. 16, 174.

Ledis, R., Carmen, P., 2011. The genus Hymenasplenium (Aspleniaceae) in Cuba, including new combinations for the neotropical species. Am. Fern J. 101(4), 265-281.

Maddison, D., Maddison, W., 2005. McClade 4. Analysis of Phylogeny and Character Evolution (CDRom 429 pages Manuel in pdf). Sinauer Associates.

Mangambu, M., 2013. Taxonomie, Biogéographie et Ecologie des Ptéridophytes de l'écosystème forestier des montagnes du Parc National de Kahuzi-Biega à l'Est de la R.D. Congo. Thèse de doctorat, Université d'Anvers/Belgique.

Mangambu, M., Robbrecht, E., J-C., Ntahobavuka, van Diggelen, R., 2014a. Analyse phytogéographique des Ptéridophytes d'Afrique centrale: cas des étages des montagnes du Parc National de Kahuzi-Biega (République Démocratique du Congo). Europ. Scient. 10 (8), 84-106.

Mangambu, M., Robbrecht, E. J-C., Ntahobavuka, van Diggelen, R., 2014b. Analysis of the Congolese distribution of ferns and allies mountainous of Kahuzi Biega National Park (Democratic Republic of the Congo): Contribution to the conservation of actual protected areas in the park. Int. J. Biol. Sci. 1(6), 01-26.

Matos, B.F., Labiak, H., Lana, S., 2009. A new Brazilian species of the genus Asplenium L. (Aspleniaceae). Am. Fern J. 99(2), 101-105.

Mickel, J. T., Beitel, J.M., 1988. Pteridophyte Flora of Oaxaca, Mexico. Mem. New York Bot. Gard. 46, 1-568. 
Mickel, J. T., Smith, A. R., 2004. Phyletic lines in the modern ferns. Ann. Miss. Bot. Gard. 85, 474-482.

Mitui, K., Murakami, N., Iwatsuki, K., 1989. Chromosomes and systematics of Asplenium sect. Hymenasplenium (Aspleniaceae). Am. J. Bot. 76, 1689-1697.

Morton, C.V., Lellinger, D.B., 1966. The Polypodiaceae subfamily Asplenioideae in Venezuela. Mem. New York Bot. Gard. 15, 1-49.

Murakami, N., Moran, R. C., 1993. Monograph of the neotropical species of Asplenium sect. Hymenasplenium (Aspleniaceae). Ann. Miss. Bot. Gard. 80, 1-38.

Murakami, N., Watanabe, M., Yokoyama, J., Uatabe, Y., Seriawa, S., 1999. Molecular taxonomic study and revision of the three Japanese species of Asplenium sect. Thamnopteris. J. Plant Res. 112, 15-25.

Murakami, Y., Murakami, Y., Siripanyaphinyo, U., Hong, Y., Tashima, Y., Maeda, Y., Kinoshita, T., 2005. The initial enzyme for glycosyl phosphatidylinositol biosynthesis requires PIG-Y, a seventh component. Mol. Biol. Cell 16(11), 5236-5246.

Nripemo, O., Dilip Kumar, R., Roy Fraser-Jenkins, C., 2012. Asplenium aethiopicum-A new distributional record for Northern India. Taiwania 57(4), 403-405.

Posada, D., Crandall, K.A., 1998. MODELTEST: testing the model of DNA substitution. Bioinfor. Note. 14(9), 817818.

Regalado, G., Carmen, P., 2011. The genus Hymenasplenium (Aspleniaceae) in Cuba, including new combinations for the neotropical species. Am. Fern J. 101(4), 265-281.

Ronquist, F., Huelsenbeck, J., 2003. MRBAYES 3: Bayesian phylogenetic inference under mixed models. Bioinfor. 19, 1572-1574.

Roux, J. P., 2009. Synopsis of the Lycodiopyta and Pteridophyta of Africa, Madagascar and neighbouring islands. Strelitzia 23. South African National Biodiversity Institute.

Roux, J.P., 2001. An enumeration of the Pteridophyta of Angola, Botswana, Lesotho, Malawi, Mozambique, Namibia, South Africa (including the Marion Island group), Swaziland, Zambia and Zimbabwe. Compton Herbarium, National Botanical Institute, Southern African Botanical Diversity. Network Report No. 13. pp.1-235.
Schneider, H., Ranker, T., Russell, S., Cranfill, R., Geiger, J., Aguraiuja, R., Wood, K., Grundmann, M., Keelie Kloberdanz, K., Vogel, J., 2005. Origin of the endemic fern genus Diellia coincides with the renewal of Hawaiian terrestrial life in the Miocene. Proc. Royal Soc. Biol. Sci. 272(1561), 455-460.

Schneider, H., Smith, A.R., Pryer, K.M., 2009. Is morphology really at odds with molecules in estimating fern phylogeny? Syst. Bot. 34, 455-475.

Schneider, H., Russell, S. J., Cox, C. J., Bakker, F., Henderson S., Rumsey, F., Barrett, J., Gibby, M., Vogel, J. C., 2004. Chloroplast phylogeny of asplenioid ferns based on $r b c L$ and trnL- $F$ spacer sequences (Polypodiidae, Aspleniaceae) and its implications for biogeography. Syst. Bot. 29, 260-274.

Singh, Y., Bir, S., 1989. Distribution, ecology and phytogeography of Asplenioid ferns of India. Ind. Fern J. 6, 268-284.

Stamatakis, A., 2006. RAxML-VI-HPC: maximum likelihoodbased phylogenetic analyses with thousands of taxa and mixed models. Bioinf. 22(21), 2688-2690.

Stamatakis, A., Ludwig, T., Meier, H., 2005. RAxML-III: a fast program for maximum likelihood-based inference of large phylogenetic trees. Bioinf. 21(4), 456-463.

Swofford, D. L., 2002. PAUP*. Phylogenetic analysis using parsimony (*and other methods). Version 4. Sinauer Associates, Sunderland, Massachusetts.

Testo, W., Watkins, J., 2011. Comparative development and gametophyte morphology of the hart's-tongue fern, Asplenium scolopendrium L. J. Torrey Bot. Soc. 138(4), 400-408.

Tryon, R., Tryon, A., 1982. Ferns and allied plants, with special reference to tropical America. Springer-Verlag, New York.

Viane, R. L. R., Reichstein, T., 1991. Notes about Asplenium: some new names and combinations in Asplenium L. (Aspleniaceae, Pteridophyta). Biol. Jb. Dodonaea 59, 157165.

Van den Heede, C. J., Viane, R. L. L., Chase, M. W., 2003. Phylogenetic analysis of Asplenium subgenus Ceterach (Pteridophyta: Aspleniaceae) based on plastid and nuclear ribosomal ITS DNA sequences. Am. J. Bot. 90, 481-495.

\section{How to cite this article:}

Mangambu, M., Janssen, S., Robbrecht, E., Janssen, T., Ntahobavuka, H.H., van Diggelen, R., 2016. A molecular investigation of Asplenium: Asplenium kivuensis nov.* - A new species from Kivu (Democratic Republic of Congo). Int. J. Curr. Res. Biosci. Plant Biol. 3(2), 27-37. doi: http://dx.doi.org/10.20546/ijcrbp.2016.302.004 